Antarctic Science 26(6), 603 (2014) @ Antarctic Science Ltd 2014. This is an Open

Access article, distributed under the terms of the Creative Commons Attribution licence

(http://creativecommons.org/licenses/by/3.0/), which permits unrestricted re-use,

distribution, and reproduction in any medium, provided the original work is properly cited.

doi:10.1017/S0954102014000388

\title{
Professor David E. Sugden - an appreciation
}

\section{GEORGE H. DENTON}

\author{
School of Earth and Climate Sciences, University of Maine, Orono, ME 04469-5790, USA \\ gdenton@maine.edu
}

Received 11 May 2014, accepted 12 May 2014

Professor David E. Sugden of the University of Edinburgh in Scotland is an extraordinary scientist whose career spans more than four decades. He has had a profound influence on numerous aspiring young students, mentoring more than 40 at graduate level. Under his tutelage, many of these students have become broad-thinking scientists who themselves have made significant contributions to an understanding of the iceage world, thus carrying on David's traditions. David's books and papers have set a new standard for research that combines glaciology and glacial geomorphology. The power of this combination is clearly expressed in his early masterful text entitled Glaciers and landscape: a geomorphological approach, which he co-authored with Brian John, published in 1976 and reprinted 13 times. This book set the scene for modern interdisciplinary studies of glacial landforms and landscapes. It also formed the basis for David's subsequent lifetime of research.

At the heart of David's work is his love for science. He attacks problems of global significance and achieves success by using a diverse toolkit and a masterful appreciation of what it means to be interdisciplinary. His early computer reconstructions in the 1970s of the dynamics and thermal regime of Northern Hemisphere ice sheets were groundbreaking, in that they utilized assemblages of subglacial landforms as proxies for past ice-sheet dynamics and thermal properties, as well as for addressing climate change. He has gone on to make seminal contributions to the glacial and climate history of Antarctica (15 trips to the southernmost continent), to the interpretations of glacial landforms in Scotland, and to the glacial history of Patagonia. A key constant throughout David's career has been his unique ability to recognize and interpret, on the basis of solid glaciological reasoning, the incredible array of glacial landforms on this planet.

David has excelled in leadership roles at all stages of his career. He has served as President of the Geography Section of the British Association, Vice President of the Royal Geographical Society, President of the Institute of British Geographers, and Director of SAGES (Scottish Alliance for Geoscience, Environment, and Society). At the University of Edinburgh, David has twice been Department Head of Geography and was also the inaugural Head of the School of Geosciences.

For his great impact on our field, David has received numerous accolades. These include the Vega Medal, the Seligman Crystal, the Polar Medal, the Linton Award, the Royal Geographical Society's Cuthbert Peek Award, and the Royal Scottish Geographical Society's Mungo Park Medal. He is a Fellow of the Royal Society of Edinburgh and has received honorary degrees from the University of Stockholm and the University of Dundee.

I cannot resist closing on a personal note. A highlight of my scientific life was the privilege of working in Antarctica for several field seasons with David in the 1990s. Those were wonderful times. To both of us the science was very exciting. Along with our colleagues from the United States and the United Kingdom, we studied antiquity, namely, the oldest landscape on Earth, in the Dry Valleys sector of the Transantarctic Mountains. Based on his observations of the geomorphology of preserved landforms, David was instrumental in sorting out the fluvial from the glacial processes that combined to produce this unique landscape. The result was the recognition that significant portions of the landscape of this passive margin of Antarctica date back well into the Cenozoic. There is an old fluvial signature to the landscape, involving coastal escarpments and erosion surfaces, together with incised river valleys. A younger glacial signature is superimposed on this old fluvial landscape, with selective erosion where the base of the ice sheet was at the pressure melting point and preservation of the old landscape where the base of the ice was cold. David has since gone on to interpret the bedrock landscape beneath the entire Antarctic ice sheet. But he is not finished. His recent work addresses a major issue that affects human civilization, namely, the global sea level changes driven from the Antarctic ice sheet. Resolution of this issue requires a detailed knowledge of the behaviour of the ice sheet during the last glacial maximum and the Holocene, as the globe transitioned from full-glacial to full-interglacial conditions. The problem is of particular concern because, as recognized more than three decades ago, the marine-based portions of the ice sheet are susceptible to unstable collapse. David's recent work is focused on the huge Weddell Sea embayment into the Antarctic ice sheet. His findings underpin a re-evaluation of the magnitude of ice volume change in this sector during the last glacial cycle, and therefore a rethinking of the contribution of the Antarctic ice sheet to sea level change.

It is particularly suitable that this special issue of Antarctic Science be dedicated to Professor David E. Sugden because he has contributed so much to our understanding of landscape evolution. 